https://helda.helsinki.fi

\title{
Welfare Effects of TTIP in a DSGE Model
}

\section{Engler, Philipp}

\section{6}

Engler , P \& Tervala , J V S 2016, ' Welfare Effects of TTIP in a DSGE Model ' , DIW Discussion Papers, no. $1625 .<$ https://www.diw.de/documents/publikationen/73/diw_01.c.548081.de/dp1625.pdf > http://hdl.handle.net/10138/176373

publishedVersion

Downloaded from Helda, University of Helsinki institutional repository.

This is an electronic reprint of the original article.

This reprint may differ from the original in pagination and typographic detail.

Please cite the original version. 
DIW BERLIN

Discussion

Papers

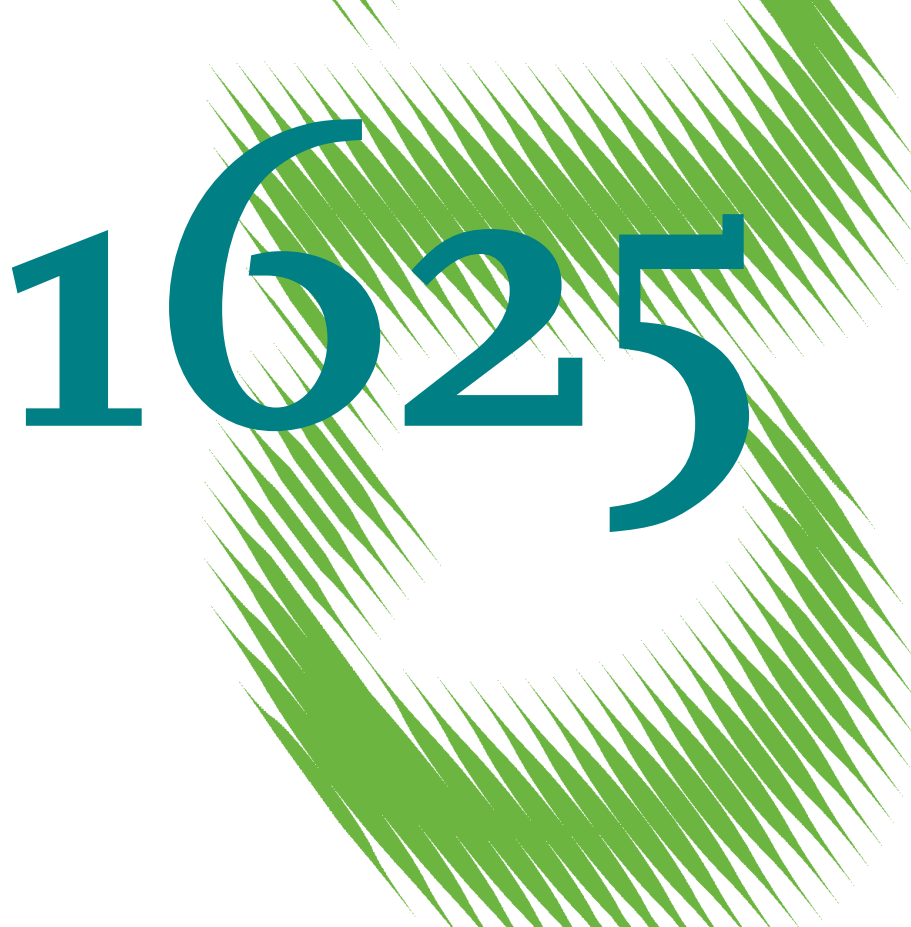

Welfare Effects of TTIP in a

DSGE Model 
Opinions expressed in this paper are those of the author(s) and do not necessarily reflect views of the institute.

IMPRESSUM

(C) DIW Berlin, 2016

DIW Berlin

German Institute for Economic Research

Mohrenstr. 58

10117 Berlin

Tel. +49 (30) $89789-0$

Fax +49 (30) $89789-200$

http://www.diw.de

ISSN electronic edition 1619-4535

Papers can be downloaded free of charge from the DIW Berlin website:

http://www.diw.de/discussionpapers

Discussion Papers of DIW Berlin are indexed in RePEc and SSRN:

http://ideas.repec.org/s/diw/diwwpp.html

http://www.ssrn.com/link/DIW-Berlin-German-Inst-Econ-Res.html 


\title{
Welfare Effects of TTIP in a DSGE Model
}

\author{
Philipp Engler and Juha Tervala
}

\begin{abstract}
Several studies have analyzed the trade and output effects of the Transatlantic Trade and Investment Partnership (TTIP) between the United States and the European Union, but our paper is the first attempt to study its welfare effects. We measure the welfare effect of TTIP as the percentage of initial consumption that households would be willing to pay for TTIP in order to remain as well off with TTIP as without it. The discounted present value of the welfare gain of TTIP, which leads to the elimination of tariffs and cuts in non-tariff measures by $25 \%$, is in the range of $1 \%$ to $4 \%$ of initial consumption, depending on the parameterization. The welfare gain increases in the elasticity of substitution between domestic and foreign goods. The bulk of the welfare gain is caused by cuts in non-tariff measures.
\end{abstract}

JEL Classification Numbers: F13; F41; E60

Keywords: Tariffs, TTIP, trade agreement, trade liberalization

Contact details:

Philipp Engler: DIW Berlin, Mohrenstr. 58, 10117 Berlin, Germany, phone: +493089789486, email: pengler@diw.de

Juha Tervala: University of Helsinki, Department of Political and Economic Studies, P.O. Box 17, 00014 University of Helsinki, Finland, phone: + 358503182244, email: juha.tervala@ helsinki.fi 


\section{Introduction}

The pros and cons of the Transatlantic Trade and Investment Partnership (TTIP) between the United States (US) and the European Union (EU) are intensely debated. Felbermayr et al. (2015a), for instance, argue that the advantages have both economic and geostrategic components: the elimination of tariffs and non-tariff measures (NTMs) between the US and the EU should increase trade and output. In addition, a regulatory cooperation should help to impose Western standards in the world trade system. Felbermayr et al. (2015a) emphasize that the critics of TTIP argue that the possible benefits are modest and fear that TTIP may trigger a race to the bottom in health, safety, labor and environmental standards.

As emphasized by Felbermayr (2015), the quantitative modeling of the pros and cons of TTIP is "a gargantuan task" and TTIP studies differ in several dimensions, but important ones are the model structure, the measurement of NTMs and the scenario definition. The latter dimension is particularly difficult, because regulatory coherence is the key of TTIP and researchers can only guess the exact nature of the partnership before its conclusion.

We participate in the TTIP debate by employing a model structure that is different from the ones previously used in the TTIP literature: a New Keynesian dynamic stochastic general equilibrium (DSGE) model, based on Ganelli and Tervala (2015), which allows us to analyze transition dynamics of TTIP. ${ }^{1}$ Ghironi (2016) argues - in the context of the Trans-Pacific

\footnotetext{
${ }^{1}$ Capaldo (2014) does use an old Keynesian model to analyze TTIP. However, Bauer and Erixon (2015) highlight that the model Capaldo (2014) uses is not designed to analyze the effects of trade agreements. Most notably, it is (continued)
} 
Partnership - that it is important to account for the transition dynamics of major trade deals, which extend far beyond reductions in tariffs. In contrast, all other main TTIP studies use trade models and are therefore unable to analyze transition dynamics.

We use the NTM estimates of Berden et al. (2009), who find that NTMs for US-EU trade are on average $18 \%$ in ad valorem equivalent terms. Our scenario is that TTIP eliminates tariffs entirely and reduces NTMs, while we ignore several key elements of TTIP. Berden et al. (2009) introduce the concept of actionability, the degree to which NTMs can realistically be reduced. They find that NTMs for US-EU trade are on average 18\%, of which roughly half are actionable, and analyze the consequences of $25 \%$ and $50 \%$ reductions in NTMs. Several economists regard a 50\% reduction in NTMs too optimistic. Following the work of Francois et al. (2013) and Fontagné et al. (2013), our baseline scenario is that TTIP leads to the elimination of tariffs and a cut in NTMs of $25 \%$. We would like to emphasize that it is beyond the capacity of all models to plausible estimate all aspects of the most comprehensive trade deal in history. Therefore, we ignore, among others, the most debated aspects of TTIP: the standards of investment protection and the Investor State Dispute Settlement.

Our main contribution is to evaluate the welfare effects of TTIP, while the earlier literature focuses on its trade and output effects. Aichele et al. (2014) and Felbermayr et al. (2015b) argue that they analyze the welfare effects of TTIP, but their welfare measure is in effect the

\footnotetext{
"a demand-driven model that does not make efforts to capture the supply-side effects of trade which are the effects that are proven to be the core positive effects of trade liberalization" Bauer and Erixon $(2015,2)$.
} 
change in real income that is equal to output. We believe that the utility function of households is the relevant welfare measure and provides the best objective in terms of which the pros and cons of TTIP should be assessed. We measure the welfare benefit of TTIP in consumption equivalent terms: as the percentage of initial consumption that households would be willing to pay for TTIP in order to remain as well off with the TTIP case as without it.

The discounted present value (DPV) of the welfare gain of TTIP is $1.5 \%$ of initial consumption under the benchmark parameterization. This means that TTIP yields the welfare improvement that corresponds to a one-off $1.5 \%$ increase in consumption. In dollar terms, the welfare gain for a US (EU) citizen corresponds to a one-off 780 (510) US dollars increase in consumption (based on the World Bank (2016) data on 2012 GDP per capita in 2014 US dollars). In the new steady state, the welfare gain of TTIP is only $0.016 \%$ of initial consumption and it corresponds to an annual 8 (5) US dollars increase in consumption for a US (EU) citizen. These results are new since the existing literature contains no analyses of the welfare effects of TTIP.

Robustness checks reveal that the welfare effects of TTIP are sensitive to changes in the Frisch elasticity of labor supply, the within-country substitutability (the elasticity of substitution between two goods produced in the same country) and the cross-country substitutability (the elasticity of substitution between domestic and foreign goods). First, a high Frisch elasticity implies a high labor supply and output response to TTIP. The more output increases, the higher the welfare effect is. Second, if the within-country substitutability is low and consequently the initial level of employment and output are low, then the welfare gain of TTIP will be higher. Third, if the cross-country substitutability is changed from the benchmark value of 3 to 6 (8), 
the welfare gain increases from $1.5 \%$ of consumption to $2.7 \%(3.8 \%)$. In an imperfectly competitive economy, an increase in employment and consumption that brings them closer to their efficient levels increases welfare. The welfare gains of TTIP, therefore, depend positively on the degree of the cross-country substitutability. If the cross-country substitutability is 8 , the DPV of the welfare gain on a US (EU) citizen corresponds to a one-off 2,000 $(1,300)$ US dollars increase in consumption.

Drozd et al. (2014) emphasize that the international trade literature shows that trade reacts notably to persistent price changes but not to temporary ones that take place on business cycle frequency and this property leads to very different estimates of the cross-country substitutability, depending on the time horizon. In international macro and trade literatures, completely different sizes of cross-country substitutabilities have been used, depending on the question at hand. In this paper, we analyze the welfare effects of trade liberalization that shifts relative prices permanently. Therefore, for the question at hand, a high cross-country substitutability may be a more realistic description of the reality, particularly in the long term.

Berden et al. (2009), Francois et al. (2013), and Fontagné et al. (2013), who analyze the identical scenario, find that TTIP increases output in the US and the EU on average by 0.2$0.4 \%$ in the long term. In our benchmark parameterization, the long-term output effect is 0.16\%. Raza et al. (2014) summarize that the output and trade effects of TTIP are sensitive to the choice of the elasticity of substitution between goods, because it governs how strongly the model will react to trade liberalization. If we set a high cross-country substitutability, as done in practice in TTIP studies, we will find that the output effects are in the same range as in 
Berden et al. (2009), Fontagné et al. (2013) and Francois et al. (2013). On the other hand, our finding, regarding the role of the elasticity of substitution between goods on the output effects of TTIP, is inconsistent with TTIP studies. Felbermayr et al. (2015b), for instance, show that lower values of the elasticity of substitution lead to a higher output effect of TTIP, since domestic and foreign goods are less easily substitutable. In our DSGE model with endogenous labor supply, domestic and foreign goods are more easily substitutable if the cross-country substitutability is high and households respond to trade liberalization by supplying more labor. The higher the cross-country substitutability, the larger the output effect of TTIP.

Following the earlier TTIP studies we also look at the effects of a TTIP agreement that is limited to liberalizing tariffs only. A tariffs-only agreement induces a considerably smaller output effect, which is in line with the other TTIP papers. Our main focus is, however, on welfare. The welfare gain of a tariffs-only agreement under the benchmark parameterization is $0.6 \%$ of consumption, which is roughly one third of the welfare gain of the baseline scenario. We can therefore conclude that the bulk of the welfare gain of TTIP is induced by cuts in NTMs.

The rest of the paper is organized as follows. Section 2 introduces the model. Section 3 presents the parameterization of it. Section 4 analyzes the effects of TTIP, focusing mostly on the welfare effects. It also examines the sensitivity of the main results to variations in key parameters values. Section 5 concludes the paper. 


\section{Model}

In this section, we introduce a New Keynesian model of trade liberalization that is based on Ganelli and Tervala (2015). We go beyond their approach in that we allow for both tariff and non-tariff barriers, because the latter constitute the major barriers to trade between the US and the EU. Furthermore, we allow trade barriers to be adjusted gradually.

The world is made up of two countries: home and foreign. Firms and households are indexed by $z \in[0,1]$. Households and firms over the $[0, \mathrm{n})$ interval are located in the home country, whereas the rest $[n, 1]$ are located in the foreign country. In the description of the model, if the equations are symmetric across countries, we present only domestic ones.

\subsection{Households}

The domestic household's lifetime utility is given by the function

$U_{t}=\sum_{s=t}^{\infty} \beta^{s-t}\left[\log C_{s}+\frac{\chi}{1-\varepsilon}\left(\frac{M_{s}}{P_{s}(\tau)}\right)^{1-\varepsilon}-\frac{l_{s}(z)^{1+1 / v}}{1+1 / v}\right]$.

In this equation $0<\beta<1$ is the discount factor, $C_{t}$ is a consumption index to be defined below, $\chi$ is a positive parameter, $M_{t}$ is nominal money balances, $\varepsilon>0$ is the inverse of the consumption elasticity of money demand, $P_{s}(\tau)$ is the consumption price index, $l_{t}(z)$ is the household's labor supply, and $v$ is the Frisch elasticity of labor supply. The expression $P(\tau)$ denotes the fact that the price index is a function of the trade barriers, which we denote as $\tau$. They are the sum of a tariff $\left(\tau_{t}^{t}\right)$ and NTMs $\left(\tau_{t}^{N T M}\right): \tau_{t}=\tau_{t}^{T}+\tau_{t}^{N T M}$. Price indexes and the effect of trade barriers on them are shown below. 
The overall consumption index is given by ${ }^{2}$

$C_{t}=\left[\kappa^{\frac{1}{\rho}}\left(C_{t}^{h}\right)^{\frac{\rho-1}{\rho}}+(1-\kappa)^{\frac{1}{\rho}}\left(C_{t}^{f}\right)^{\frac{\rho-1}{\rho}}\right]^{\frac{\rho}{\rho-1}}$,

where $C_{t}^{h}$ and $C_{t}^{f}$ represents the consumption of domestic and foreign goods, respectively, and $\rho>0$ is the cross-country substitutability. $\kappa \equiv n \alpha(0<\kappa<1)$ denotes the share of domestic goods in the consumption basket, which depends on the relative size of the home country $(n)$ and the degree of home bias in consumption $(\alpha>1) . C_{t}^{h}$ and $C_{t}^{f}$ are aggregates of domestic and foreign goods,

$$
\begin{aligned}
C_{t}^{h} & =\left[n^{-\frac{1}{\theta}} \int_{0}^{n} c_{t}^{h}(z)^{\frac{\theta-1}{\theta}} d z\right]^{\frac{\theta}{\theta-1}} \\
C_{t}^{f} & =\left[(1-n)^{-\frac{1}{\theta}} \int_{n}^{1} c_{t}^{f}(z)^{\frac{\theta-1}{\theta}} d z\right]^{\frac{\theta}{\theta-1}},
\end{aligned}
$$

where $c_{t}^{h}(z)$ and $c_{t}^{f}(z)$ are the respective consumption levels of differentiated domestic and foreign $\operatorname{good} z$ by the domestic household, and $\theta>1$ is the within-country substitutability.

\footnotetext{
${ }^{2}$ The foreign consumption index is $C_{t}^{*}=\left[\kappa^{* \frac{1}{\rho}}\left(C_{t}^{* h}\right)^{\frac{\rho-1}{\rho}}+\left(1-\kappa^{*}\right)^{\frac{1}{\rho}}\left(C_{t}^{* f}\right)^{\frac{\rho-1}{\rho}}\right]^{\frac{\rho}{\rho-1}}$, where asterisks indicate consumption by the foreign household. $\kappa^{*} \equiv n \alpha^{*}\left(0<\kappa^{*}<1\right)$ denotes the share of domestic goods in the foreign consumption basket. Home bias requires $\alpha^{*}<1$.
} 
We assume, for the sake of simplicity, that both countries impose (ad valorem) tariffs and NTMs on all imported goods. The optimal allocation of consumption between different types of goods is governed by the following demand functions: ${ }^{3}$

$c_{t}^{h}(z)=\left[\frac{p_{t}^{h}(z)}{P_{t}^{h}}\right]^{-\theta}\left[\frac{P_{t}^{h}}{P_{t}(\tau)}\right]^{-\rho} \alpha C_{t} \quad$ and $\quad c_{t}^{f}(z)=\left[\frac{\left(1+\tau_{t}\right) p_{t}^{f}(z)}{P_{t}^{f}(\tau)}\right]^{-\theta}\left[\frac{P_{t}^{f}(\tau)}{P_{t}(\tau)}\right]^{-\rho}\left(\frac{1-\kappa}{1-n}\right) C_{t}$.

The consumer price index is $P_{t}(\tau)=\left[\kappa\left(P_{t}^{h}\right)^{1-\rho}+(1-\kappa) P_{t}^{f}(\tau)^{1-\rho}\right]^{1-\rho}$, the domestic price index is $P_{t}^{h}=\left[n^{-1} \int_{0}^{n} p_{t}^{h}(z)^{1-\theta} d z\right]^{\frac{1}{1-\theta}}$ and the foreign goods price index is $P_{t}^{f}(\tau)=\left[(1-n)^{-1} \int_{n}^{1}\left(\left(1+\tau_{t}\right) p_{t}^{f}(z)\right)^{1-\theta} d z\right]^{\frac{1}{1-\theta}}$. As in Fender and Yip (2000), the law of one price holds for producer prices but not for consumer prices in our model. Households allocate their total consumption between domestic and foreign goods, taking into account relative prices (including trade barriers), the cross-country substitutability, and the degree of home bias in consumption. The effect of trade liberalization is clearly visible here: a reduction in trade barriers reduces the price of imported goods and thereby the consumer price index.

\footnotetext{
${ }^{3}$ The corresponding foreign equations are

$c_{t}^{* h}(z)=\left[\frac{\left(1+\tau_{t}^{*}\right) p_{t}^{* h}(z)}{P_{t}^{* h}(\tau)}\right]^{-\theta}\left[\frac{P_{t}^{* h}(\tau)}{P_{t}^{*}(\tau)}\right]^{-\rho} \alpha^{*} C_{t}^{*} \quad c_{t}^{* f}(z)=\left[\frac{p_{t}^{* f}(z)}{P_{t}^{* f}}\right]^{-\theta}\left[\frac{P_{t}^{* f}}{P_{t}^{*}(\tau)}\right]^{-\rho}\left(\frac{1-\kappa^{*}}{1-n}\right) C_{t}^{*}$.
} 
The budget constraint of the domestic household is given by ${ }^{4}$

$$
M_{t}+D_{t}=\left(1+t_{t-1}\right) D_{t-1}+M_{t-1}+w_{t} l_{t}(z)-P_{t}(\tau) C_{t}+\pi_{t}+P_{t}(\tau) T_{t}
$$

where $D_{t-1}$ denotes an internationally traded bond purchased in period $t$ - 1 that pays one unit of domestic currency plus the nominal interest rate $i_{t-1}$ in period $t$. The term $w_{t}$ represents the nominal wage rate, $\pi_{t}$ is nominal dividends (profits), and $T_{t}$ denotes real transfers from the government.

The optimal choices with respect to the intertemporal allocation of consumption, the labor supply and money demand is given by

$$
\begin{aligned}
& \beta\left(1+i_{t}\right) \frac{P_{t}(\tau) C_{t}}{P_{t+1}(\tau) C_{t+1}}=1, \\
& l_{t}(z)=\left(\frac{w_{t}}{C_{t} P_{t}(\tau)}\right)^{v} \text { and } \\
& \frac{M_{t}}{P_{t}(\tau)}=\left(\chi C_{t} \frac{1+i_{t}}{i_{t}}\right)^{\frac{1}{\varepsilon}} .
\end{aligned}
$$

\footnotetext{
${ }^{4}$ The budget constraint of the foreign household, because the bond is denominated in the domestic currency, is

$M_{t}^{*}+D_{t}^{*} / S_{t}=\left(1+i_{t-1}\right)\left(D_{t-1}^{*} / S_{t}\right)+M_{t-1}^{*}+w_{t}^{*} l_{t}^{*}(z)-P_{t}^{*}\left(\tau^{*}\right) C_{t}^{*}+\pi_{t}^{*}+P_{t}^{*}\left(\tau^{*}\right) T_{t}^{*}$

where $S_{t}$ is the nominal exchange rate, defined as the price of the foreign currency, expressed in the domestic currency. A global asset-market clearing condition requires that $n D_{t}+(1-n) D_{t}^{*}=0$.
} 
Equations (6) is a consumption Euler equation. Equation (7) shows that a reduction in trade barriers increases the supply of labor by decreasing the price level and thereby increasing the real wage. Equation (8) determines the demand for money.

\subsection{Government and Trade Liberalization}

We assume, for the sake of simplicity, that the government repays tariff and seignorage revenues to households in a lump-sum manner. The government budget constraint, in percapita terms, can be written as ${ }^{5}$

$P_{t}(\tau) T_{t}=\tau_{t}^{T} c_{t}^{f}(z) p_{t}^{*}(z) S_{t}+M_{t}-M_{t-1}$.

In equation (9), the first term on the right hand side is revenue from import tariffs. It depends on the tariff rate $\left(\tau_{t}^{T}\right)$, consumption of foreign goods, and their domestic currency price.

Our way to analyze the effects of TTIP differs from the traditional approach in that we also analyze transition dynamics, rather than just the long-term effect. For that reason, the timing of the implementation of liberalization measures is crucial. Therefore, we have to model trade liberalization caused by TTIP differently. Petri and Plummer (2016) emphasize-in the context of the Trans-Pacific Partnership - that trade policy is gradual. Because this seems reasonable for TTIP as well, we assume that it will have a gradual effect on transatlantic trade barriers.

We assume that the change in effective trade barriers is given by

$$
\hat{\tau}_{t+1}=(1-\lambda) \hat{\tau}_{t}+\hat{\varepsilon}_{t}
$$

\footnotetext{
${ }^{5}$ The foreign tariff revenue $\left(R^{*}\right)$ from import tariffs is $R_{t}^{*}=\tau_{t}^{T^{*}} c_{t}^{h^{*}}(z) p_{t}(z)\left(1 / S_{t}\right)$.
} 
where $\lambda$ is - loosely speaking - the "depreciation rate of trade liberalization" and $\hat{\varepsilon}_{t}$ represents an unexpected change in trade barriers. Percentage changes from the initial steady state (denoted by the subscript zero) are denoted by hats; for example, $\hat{\tau}_{t}=d \tau_{t} / \tau_{0}$. Trade liberalization is modeled as a permanent negative shock to trade barriers. Equation (10) captures the idea that a trade policy change caused by the TTIP deal is gradual and after some time the steady-state level of trade barriers is lower than before.

Finally, we assume a constant supply of nominal money balances, that is, $M_{t}-M_{t-1}=0$ for all $t$. This implies that lump-sum transfers from the government to household are equal to tariff revenues.

\subsection{Firms}

The domestic firm maximizes its profits

$\pi_{t}(z)=p_{t}^{h}(z) y_{t}(z)-w_{t} l_{t}(z)$,

taking into account the production function $y_{t}(z)=l_{t}(z)$ and the demand curve for its goods.

The trade barriers do not appear in equation (11), because we assume that they are borne by consumers. However, because the demand functions of consumers are affected by trade barriers, there is an indirect effect on profits. As shown in Ganelli and Tervala (2015), the profits can be written as

$$
\begin{aligned}
& \pi_{t}(z)=\left[p_{t}^{h}(z)-w_{t}\right] \times \\
& \left\{\left[\frac{p_{t}^{h}(z)}{P_{t}^{h}}\right]^{-\theta}\left[\frac{P_{t}^{h}}{P_{t}(\tau)}\right]^{-\rho} \kappa C_{t}+\left[\frac{\left(1+\tau_{t}^{*}\right) p_{t}^{h}(z)}{S_{t} P_{t}^{* h}(\tau)}\right]^{-\theta}\left[\frac{S_{t} P_{t}^{* h}(\tau)}{S_{t} P_{t}^{*}(\tau)}\right]^{-\rho}(1-n) \alpha^{*} C_{t}^{*}\right\} .
\end{aligned}
$$


As shown in Ganelli and Tervala (2015), the optimal price under Calvo pricing (Calvo 1983) is

$$
p_{t}^{h}(z)=\frac{\theta}{\theta-1} \frac{\sum_{s=t}^{\infty} \gamma^{s-t} \zeta_{t, s} Q_{s} w_{t}}{\sum_{s=t}^{\infty} \gamma^{s-t} \zeta_{t, s} Q_{s}}
$$

where $\zeta_{t, s}$ is the stochastic discount factor between periods $t$ and $s$, and

$$
Q_{t}=\left[\frac{1}{P_{t}^{h}}\right]^{-\theta}\left[\frac{P_{t}^{h}}{P_{t}(\tau)}\right]^{-\rho} \kappa C_{t}+\left[\frac{\left(1+\tau_{t}^{*}\right)}{S_{t} P_{t}^{* h}(\tau)}\right]^{-\theta}\left[\frac{S_{t} P_{t}^{* h}(\tau)}{S_{t} P_{t}^{*}(\tau)}\right]^{-\rho}(1-n) \alpha^{*} C_{t}^{*}
$$

The log-linear version of equation (13) can be written as

$\hat{p}_{t}^{h}(z)=\beta \gamma \hat{p}_{t+1}^{h}(z)+(1-\beta \gamma) \hat{w}_{t}$

The change in the optimal price is thus a weighted average of the changes in current and future nominal marginal costs, which in this model are solely determined by nominal wages.

\subsection{Consolidated Budget Constraint}

As shown in Ganelli and Tervala (2015), the consolidated budget constraint for the domestic economy can be written as

$$
P_{t} C_{t}=D_{t-1}-\delta_{t} D_{t}+p_{t}^{h}(z) y_{t}(z)
$$

where $P_{t}$ is the domestic price index without trade barriers.

The model is log-linearized around a symmetric steady state, where initial net foreign assets are zero $\left(D_{0}=0\right)$. Equation (15) therefore implies that $C_{0}=y_{0}$. As in Ganelli and Tervala (2015), the initial level of employment and output is 
$l_{0}(z)=y_{0}(z)=\left[\frac{\theta-1}{\theta} \frac{p_{0}(z)}{P_{0}(\tau)}\right]^{\frac{1}{1+1 / v}}$

This equation illustrates that the level of output depends on trade barriers and the withincountry substitutability. Trade barriers increase the price level, and this in turn reduces the labor supply and output.

\section{Parameterization}

The parameterization of the model, summarized in Table 1, is chosen to match the features of the US and the EU. We choose 2012 as the base year in order to make the comparisons to the other TTIP studies easier. In 2012, the GDPs of the US (roughly 16,200 USD billions) and the EU were (roughly 16,600 USD billions) almost of equal size (Felbermayr 2014). We set the relative size of the home country $(n)$ to 0.5 . This simplifies the analysis.

We interpret periods as quarters. Thus the discount factor is set to 0.99. The consumption elasticity of money demand $(1 / \varepsilon)$ is set to 1 , based on Mankiw and Summers (1986). The Frisch elasticity of labor supply ( $\boldsymbol{v}$ ) is set to 1 , based on Keane and Rogerson (2012).

The within-country substitutability $(\theta)$ is set to 11 , based on the estimates of Basu and Fernald (1997). This implies a 10\% price markup in the steady state. As discussed in Ganelli and Tervala (2015), in a model with endogenous labor supply, the degree of the within-country substitutability is a key parameter for the welfare analysis of trade reforms, because it affects the initial output level (though not the response of the economy to shocks). If the within- 
country substitutability is low, then initial output is low and an increase in output and consumption (of given size) increases welfare substantially.

As highlighted by Drozd et al. (2014), the empirical literature points out that international trade reacts substantially to persistent price changes but not to temporary ones that take place on business cycle frequency. This implies that the estimates of the cross-country substitutability differ significantly, depending on the time horizon, with lower short-term estimates than longterm estimates. Consequently, they highlight that different estimates have been used in international macroeconomics and trade, depending on the question at hand. In international macroeconomics, which focuses on high-frequency time-series predictions of models, it is typical to use low short-term estimates, whereas in the trade literature, which focuses on crosssectional implications, high long-term estimates are typically used.

On one hand, in international macroeconomics, the cross-country substitutability is often set to the range of 1 to 2 . On the other hand, referring to the empirical work of Anderson and van Wincoop (2004) and Bergstrand et al. (2013), Felbermayr et al. (2015b) argue that the trade elasticity — the elasticity of substitution between goods minus one — of 7 is plausible for models that use aggregate trade flows. Our baseline choice for the cross-country substitutability is 3 . This is a compromise between values used in the macro and trade literature, and is roughly consistent with the findings of Feenstra et al. (2014), who use a consumption index similar to ours. They find that the median estimates of the micro elasticity (elasticity between alternative import suppliers) are between 3.2 and 4.1, whereas the macro elasticity (elasticity between domestic and foreign suppliers) may be somewhat lower. We later assess how sensitive the 
welfare effects of TTIP are to changes in the cross-country substitutability in particular, since higher values may be more realistic in the long term.

Table 1. Parameterization of the Model

\begin{tabular}{|c|c|c|}
\hline Parameter & Baseline value & Description \\
\hline$\beta$ & 0.99 & Discount factor \\
\hline$\varepsilon$ & 0.5 & $\begin{array}{c}\text { Relative size of the } \\
\text { domestic economy }\end{array}$ \\
\hline$\varepsilon$ & 1 & $\begin{array}{c}\text { Inverse of the } \\
\text { consumption elasticity of } \\
\text { money demand }\end{array}$ \\
\hline$\nu$ & 1 & $\begin{array}{c}\text { Frisch elasticity of labor } \\
\text { supply }\end{array}$ \\
\hline$\theta$ & 3 & $\begin{array}{c}\text { Within-country } \\
\text { substitutability }\end{array}$ \\
\hline$\rho$ & 0.75 & $\begin{array}{c}\text { Cross-country } \\
\text { substitutability }\end{array}$ \\
\hline$\gamma$ & 0.028 & Calvo parameter \\
\hline$\tau^{T B}$ & 0.181 & Initial tariff rate \\
\hline$\tau^{N T}$ & 0.2 & Initial NTM \\
\hline$\lambda$ & & $\begin{array}{c}\text { Depreciation rate of trade } \\
\text { liberalization }\end{array}$ \\
\hline$\hat{\varepsilon}_{t}$ & $-((1-(0.136 / 0.209)) \times 20)$ & Trade liberalization shock \\
\hline$\alpha$ & 1.895 & Home bias parameter \\
\hline$\alpha^{*}$ & 0.105 & Home bias parameter \\
\hline
\end{tabular}

Gopinath and Rigobon (2008) discover that the trade-weighted median price duration of US exports and imports is roughly one year. Based on this, we set the Calvo parameter $(\gamma)$ to 0.75 so that the average delay between price adjustments is one year (four periods).

Trade barriers are the sum of tariffs and NTMs. Fontagné et al. (2013) find that the ad valorem tariff rate on bilateral trade is on average $2.2 \%$ in the US and $3.3 \%$ in the EU. We set the tariff 
rate to the average of these numbers, $2.8 \%$. The TTIP literature has used the NTM estimates of Berden et al. (2009). They find (their Table 4.2) that the costs of NTMs for US exports to the EU and for EU exports to the US are on average $18.5 \%$ and $17.7 \%$, respectively, in ad valorem equivalent terms. We set NTMs to $18.1 \%$, which is the average of these numbers. So the initial overall trade barrier is $20.9 \%$.

Berden et al. (2009) introduce the concept of actionability, the degree to which NTMs can realistically be reduced in a period of 10 years. They find that up to roughly $50 \%$ of all NTMs are actionable. Therefore, they analyze the consequences of $25 \%$ and $50 \%$ reductions in NTMs. Raza et al. (2014), for instance, debate that a 50\% reduction in NTMs is too optimistic. Francois et al. (2013) and Fontagné et al. (2013) analyze trade liberalization that leads to a cut in the tariff rate of $98-100 \%$ and a cut in NTMs of $25 \%$. We assume that TTIP leads to the elimination of tariffs and a cut in NTMs of $25 \%$. This means that the trade barrier is reduced from $20.9 \%$ to $13.6 \%$.

As mentioned earlier, a key difference of our model relative to the earlier TTIP literature is that we also analyze the short- and medium-term adjustment of the economy. In the basic case, we assume that the "depreciation rate of trade liberalization" $(\lambda)$ is 0.2 and the size of the permanent trade liberalization shock $\left(\hat{\varepsilon}_{t}\right)$ is $-((1-(0.136 / 0.209)) \times 100 \times \lambda)$. Together, these parameters imply that trade barriers are gradually reduced from $20.9 \%$ to $13.6 \%$.

Home bias parameters ( $\alpha$ and $\alpha^{*}$ ) are set such that the import-to-GDP ratios match the USEU trade. However, we have to simplify the analysis assuming balanced trade. Consequently, 
the share of imports is identical in both countries, which means that $\alpha^{*}=(1-n \alpha) / n$. According to Felbermayr (2014), EU exports to the US were roughly 550 USD billions, while US exports to EU were roughly 455 USD billions in 2012. Therefore, the EU import-to-US GDP ratio was somewhat above 3\%, while the US import-to-EU GDP ratio somewhat below $3 \%$. We set $\alpha$ to 1.895 and $\alpha^{*}$ to 0.105 , implying that the initial import-to-GDP ratio is $3 \%$ in both countries. ${ }^{6}$

\section{Welfare Effects of TTIP}

In this section, we analyze the welfare consequences of TTIP. Following the idea of SchmittGrohe and Uribe (2007), we measure the welfare benefit of trade liberalization as the percentage of consumption that households would be willing to pay for liberalization in order to remain as well off with the liberalization case as without it. As shown in Ganelli and Tervala (2015), the percentage of initial consumption that the household is willing to pay for trade liberalization $\left(\omega_{t}\right)$, referred to as the value of trade liberalization in the figure, in period $t$ is

$$
\omega_{t}=100 \times\left[\exp (1-\beta)\left(\hat{C}_{t}-l_{0}^{1+1 / v} \hat{l}_{t}\right)-1\right]
$$

The DPV of the welfare effect as a percentage of initial consumption is

$$
\omega_{D P V}=100 \times\left[\exp (1-\beta)\left(\sum_{s=t}^{\infty} \beta^{s-t}\left(\hat{C}_{s}-l_{0}^{1+1 / v} \hat{l}_{s}\right)\right)-1\right]
$$

Equation (18) illustrates that the welfare effect of TTIP depends on the changes in consumption and labor supply and the initial level of labor supply.

\footnotetext{
${ }^{6}$ We use the method of Klein (2000) and McCallum (2001) to simulate the model.
} 


\subsection{Results for the Baseline Calibration}

In this section, we analyze the consequences of TTIP. Figure 1 shows the effects of TTIP, which is signed in period 1 on the main variables. The horizontal axes indicate time in all figures. The vertical axes in panels (a) and (d) show percentage deviations of output and international trade from the initial steady state. Figure 1(c) shows the level of trade barriers. The value of trade liberalization, shown in Figure 1(b), is measured as a percentage of initial consumption.

Figure 1. Dynamic Effects of TTIP
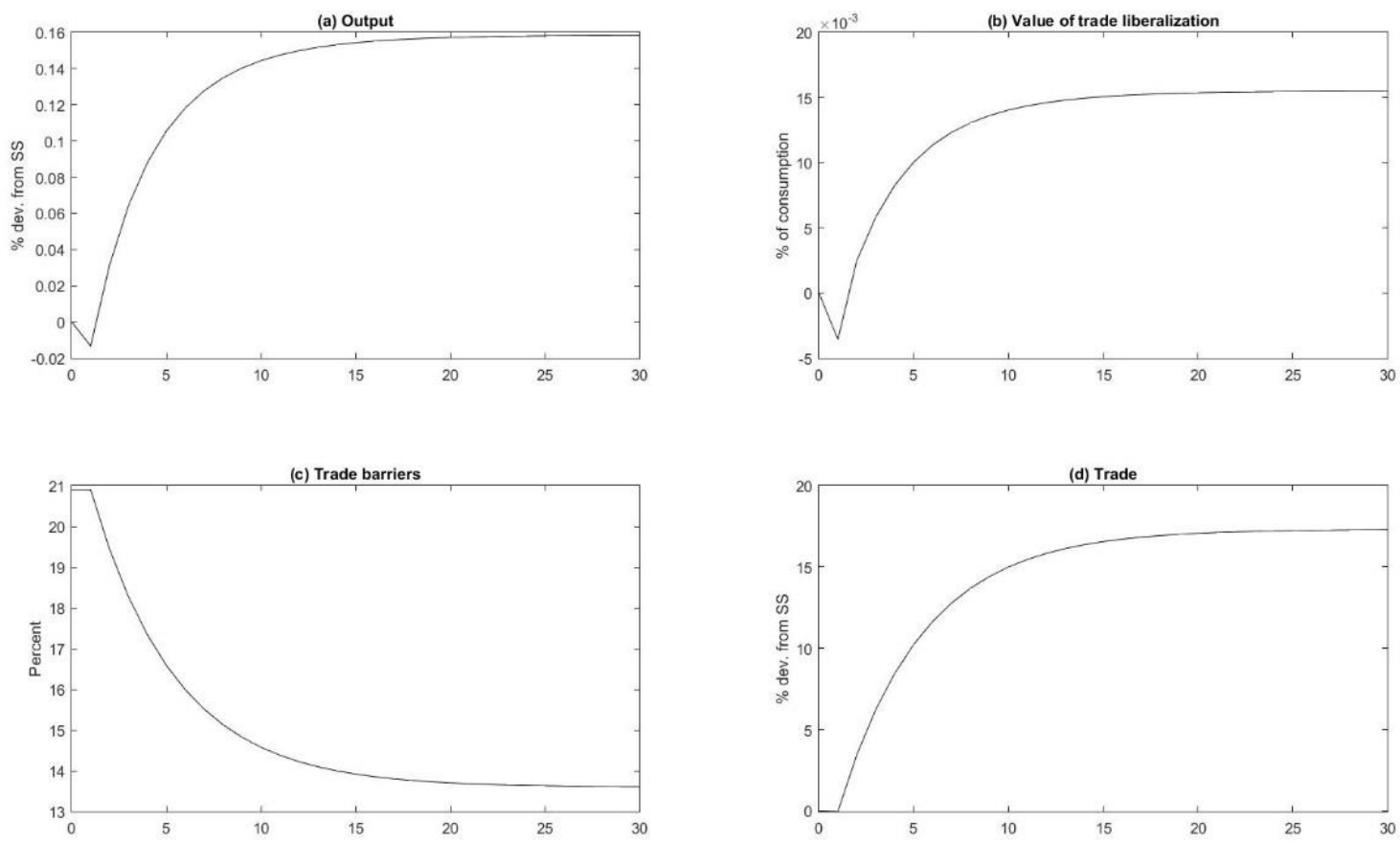

Figure 1(c) shows that trade barriers are gradually reduced. Our way of modelling of trade barriers implies that they begin to decrease one quarter after the TTIP deal is signed. Trade liberalization reduces distortions on the labor supply (recall equation (7)), because it increases 
real wages by decreasing the consumer price level. Figure 1(a) illustrates that TTIP increases output gradually, which is due to the gradual reduction in trade barriers that exert a gradual deflationary pressure. One year after the TTIP deal is signed, output has increased $0.08 \%$, while the long-term effect is $0.16 \% .^{7}$ Countries and shocks are identical, and consequently TTIP increases output in both countries by the same amount. The positive output effect of trade liberalization is consistent with the empirical evidence of Dollar and Kraay (2004). Berden et al. (2009) is the only paper in previous literature that analyzes the short-term output effects ("an immediate impact") of TTIP. They find that output increases in the short term by $0.05 \%$ in the US and $0.11 \%$ in the EU. In our paper, the output effect one year after the shock is in line with these results.

Table 2 gives an overview of the related TTIP literature and summarizes the main findings of our paper and other TTIP studies. ${ }^{8}$ Table 2 shows that our finding regarding the size of the

Table 2. Basic Assumptions and Main Results

\begin{tabular}{|l|c|c|c|c|c|c|}
\hline This study & $\begin{array}{c}\text { Berden } \\
\text { et al. } \\
(2009)\end{array}$ & $\begin{array}{c}\text { Fontagné } \\
\text { et al. } \\
(2013)\end{array}$ & $\begin{array}{c}\text { Francois et } \\
\text { al. (2013) }\end{array}$ & $\begin{array}{c}\text { Felbermayr } \\
\text { et al. } \\
(2015 b)\end{array}$ & $\begin{array}{c}\text { Aichele } \\
\text { et al. } \\
(2014)\end{array}$ \\
\hline \multicolumn{6}{|c|}{ Basic assumptions } \\
\hline
\end{tabular}

\footnotetext{
${ }^{7}$ One can see that in the quarter when TTIP is signed, output drops slightly. This is caused by the expectation of reduced trade barriers in the next period while the presence hasn't changed much yet: households expect prices to fall from then on and the incentives to work and consume more to increase. But in the initial period, neither the marginal utility of holding real money balances (due to the constant nominal money supply) nor the incentive to work more hours are much affected, while the real interest rate rises due to the expected deflation. This latter effect results in a fall in current consumption.

${ }^{8}$ Several papers address the effects of TTIP. We compare our results with studies that we regard as most closely related.
} 


\begin{tabular}{|c|c|c|c|c|c|c|}
\hline Model type & DSGE & $\begin{array}{c}\text { CGE } \\
\text { (GTAP7) }\end{array}$ & $\begin{array}{c}\text { CGE } \\
\text { (GTAP) }\end{array}$ & $\begin{array}{c}\text { CGE } \\
\text { (GTAP8) }\end{array}$ & $\begin{array}{l}\text { Gravity } \\
\text { model }\end{array}$ & $\begin{array}{c}\text { Gravity } \\
\text { model }\end{array}$ \\
\hline $\begin{array}{l}\text { Name of } \\
\text { reference } \\
\text { scenario }\end{array}$ & $\begin{array}{l}\text { Baseline } \\
\text { scenario }\end{array}$ & $\begin{array}{l}\text { Limited } \\
\text { scenario }\end{array}$ & $\begin{array}{l}\text { Reference } \\
\text { scenario }\end{array}$ & $\begin{array}{l}\text { Ambitious } \\
\text { experiment }\end{array}$ & Benchmark & $\begin{array}{l}\text { Deep } \\
\text { TTIP }\end{array}$ \\
\hline $\begin{array}{c}\text { Tariff } \\
\text { reduction }\end{array}$ & $100 \%$ & $\begin{array}{c}\text { Goods: } \\
\text { 100\%; } \\
\text { services } \\
75 \%\end{array}$ & $100 \%$ & $100 \%$ & $100 \%$ & $100 \%$ \\
\hline $\begin{array}{c}\text { NTM } \\
\text { reduction } \\
\text { in reference } \\
\text { scenario }\end{array}$ & $25 \%$ & $25 \%$ & $25 \%$ & $25 \%$ & $\begin{array}{c}\text { Trade } \\
\text { creation by } \\
\text { RTA }\end{array}$ & $\begin{array}{c}\text { Trade } \\
\text { creation } \\
\text { by RTA }\end{array}$ \\
\hline $\begin{array}{c}\text { Forecasting } \\
\text { period }\end{array}$ & $\begin{array}{c}\text { Dynamic } \\
\text { model; } 2012 \\
\text { base year }\end{array}$ & $\begin{array}{c}10 \text { years; } \\
2008- \\
2018\end{array}$ & $\begin{array}{c}10 \text { years; } \\
2015- \\
2025\end{array}$ & $\begin{array}{c}10 \text { years; } \\
2017-2027\end{array}$ & $\begin{array}{c}\text { Unclear; } \\
2012 \text { base } \\
\text { year }\end{array}$ & $\begin{array}{c}\text { Unclear; } \\
2007 \\
\text { base } \\
\text { year }\end{array}$ \\
\hline \multicolumn{7}{|c|}{ Main findings } \\
\hline EU GDP & $0.16 \%$ & $0.32 \%$ & $0.3 \%$ & $0.48 \%$ & $\begin{array}{l}3.9 \%(\mathrm{EU} \\
\text { average) }\end{array}$ & $2.12 \%$ \\
\hline US GDP & $0.16 \%$ & $0.13 \%$ & $0.3 \%$ & $0.39 \%$ & $4.9 \%$ & $2.68 \%$ \\
\hline $\begin{array}{c}\text { Change in } \\
\text { EU exports } \\
\text { to US }\end{array}$ & $17 \%$ & $0.9 \%$ & $7.6 \%$ & $28.0 \%$ & & $212 \%$ \\
\hline $\begin{array}{c}\text { Change in } \\
\text { US exports } \\
\text { to EU }\end{array}$ & $17 \%$ & $2.7 \%$ & $10.1 \%$ & $36.6 \%$ & & $171 \%$ \\
\hline Welfare & $\begin{array}{c}1.5 \% \text { of } \\
\text { consumption }\end{array}$ & & & & & \\
\hline
\end{tabular}

long-term output effect is smaller than in Berden et al. (2009), Fontagné et al. (2013) and Francois et al. (2013). A common factor of all these studies is a rather small increase in GDP. Aichele et al. (2014) and Felbermayr et al. (2015b) find a much larger output effect. The key difference is that their scenario is different: a NTM reduction in the reference scenario corresponds to the estimated trade creation effects of previous regional trade agreements 
(RTA). Therefore, the size of trade liberalization is much larger, and this explains the remarkable difference in output and trade effects.

Figure 1(d) illustrates that international trade increases gradually following gradual liberalization. The trade effect in our model is much larger than in Berden et al. (2009) and Fontagné et al. (2013), but smaller than in Francois et al. (2013). The trade effect in Aichele et al. (2014) is completely different. This is due to the different scenario. Consequently, a comparison of our results with theirs is difficult to manage.

Figure 1(b) plots the welfare effect, measured by the percentage of initial consumption that the household is willing to pay for TTIP in each period, as shown by equation (17). It shows that households are willing to pay $0.004 \%$ of their initial consumption to avoid TTIP in the first period, which means that the welfare effect is negative. However, the welfare effect soon turns positive. In an imperfectly competitive economy, an increase in output and consumption that brings them closer to their efficient levels increases welfare. In the new steady state, TTIP yields a welfare gain that corresponds to a $0.0016 \%$ increase in private consumption. Based on the World Bank (2016) data on 2012 (the base year) GDP per capita in 2014 US dollars, the annual welfare benefit of TTIP on a US (EU) citizen corresponds to an 8 (5) dollar increase in consumption in the steady state.

Table 2 shows that the DPV of the welfare gain of TTIP is $1.5 \%$ of initial consumption. We would like to emphasize that this is defined as the one period consumption equivalent change in the DPV of flow utility for TTIP. Under the baseline parameterization, households are 
willing to pay $1.5 \%$ of their initial consumption for TTIP in order to remain as well off with the TTIP case as without it. The DPV of the welfare gain of TTIP on a US (EU) citizen, based on the World Bank (2016) data on 2012 GDP per capita in 2014 US dollars, corresponds to a one-off (roughly) 780 (510) US dollars increase in consumption. These results are new, since the existing literature has not assessed the welfare effects of TTIP.

\subsection{Robustness Checks: Varying Parameters}

In this section, we check out how sensitive the main results are to changes in key parameter values. We first analyze the role of the Frisch elasticity of labor supply and the within-country substitutability, and then we shed light on the cross-country substitutability. Table 3 demonstrates the dependence of the welfare effects of TTIP on the within-country substitutability and the Frisch elasticity. The within-country substitutability is usually set in the range of 6 to 20 in macro models, implying a massive range of markups between $20 \%$ and $5 \%$, also implying a range of possible initial output and consumption levels. We therefore employ these two boundary values in order to shed light on the upper and lower bounds of the welfare effects of TTIP.

Keane and Rogerson (2012) find that the Frisch elasticity can be as high as 2, whereas Chetty et al. (2013) argue that it should be set to 0.5 on the intensive margin. Therefore, we vary it between 0.5 and 2. The main innovation of Ganelli and Tervala (2015), relative to the existing models in the literature on trade agreements, was to show that the welfare effects of trade liberalization are sensitive to the Frisch elasticity, because an endogenous labor supply changes the underlying steady state. 
First, Table 3 reveals that an increase in the Frisch elasticity implies an increase in the welfare effect of TTIP. This is because the stronger the labor supply response to trade liberalization is, the stronger the boosts to output and consumption. Second, the lower the within-country substitutability is, the bigger the welfare effect. This is because a low elasticity implies a low initial level of employment and output so that an increase in output and consumption will increase welfare more. Overall, Table 3 shows that the range of possible values of these two elasticities allows for welfare effects in the range of $0.59 \%$ and $3.6 \%$ of initial consumption.

Table 3. The Welfare Effects of TTIP: The Role of Different Within-Country Substitutabilities and Frisch Elasticities

\begin{tabular}{|c|c|c|c|}
\hline & $\theta=6$ & $\begin{array}{c}\theta=11 \\
\text { (benchmark) }\end{array}$ & $\theta=20$ \\
\hline$v=0.5$ & 1.7 & 1.0 & 0.59 \\
\hline $\begin{array}{c}v=1 \\
\text { (benchmark) }\end{array}$ & 2.7 & 1.5 & 0.90 \\
\hline$v=2$ & 3.6 & 2.0 & 1.2 \\
\hline
\end{tabular}

Raza et al. (2014) highlight that the elasticity of substitution between goods is crucial for TTIP studies, because it governs how strongly the model will react to trade liberalization. In our model, the cross-country substitutability can differ from the within-country substitutability. The latter affects only the level of initial employment and output, but not the response of the economy. Consequently, in our model, the cross-country substitutability is important.

Raza et al. (2014) calculate that the unweighted elasticity of substitution between goods used in Berden et al. (2009) is 6. Unfortunately, Fontagné et al. (2013) do not mention the used 
elasticity of substitution at all. The unweighted elasticity of substitution used in Francois et al. (2013, Table 5) is 6.3. Felbermayr et al. (2015b) set the trade elasticity - the elasticity of trade with respect to trade costs - to 7 in their benchmark parameterization. They also discuss that the elasticity of substitution between goods, which measures how changes in the price for foreign goods influences demand for foreign goods, and the trade elasticity are closely related, since the trade elasticity is equal to the elasticity of substitution minus 1 . In our model, the cross-country substitutability measures alone how fluctuations in the price for foreign goods affect demand for foreign goods. Consequently, the cross-country substitutability plus 1 is equal to the trade elasticity. So Felbermayr et al. (2015b) set effectively the cross-country substitutability to 8. In Aichele et al. (2014), the average elasticity of substitution between goods is 5.6. In alternative parameterizations, we set the cross-country substitutability to 6, as in Berden et al. (2009) and Aichele et al. (2014), and to 8, as in Felbermayr et al. (2015b).

Table 4 shows the consequences of varying the cross-country substitutability, while we keep the import-to-GDP ratio constant at $3 \%$ by changing the home bias parameters. Felbermayr et al. (2015b), for instance, show that lower values of the elasticity of substitution lead to a higher output effect of TTIP, since domestic and foreign goods are less easily substitutable. Table 4 illustrates that we find the opposite. One of the features of the framework (Ganelli and Tervala 2015) used in this paper is to alter the underlying steady state of the trade models by the introduction of endogenous labor supply. If the cross-country substitutability is high, domestic and foreign goods are more easily substitutable and households respond by supplying more labor. Consequently, TTIP further increases trade and output. In an imperfectly competitive economy with endogenous labor supply, an equal increase in employment and consumption 
that brings them closer to their efficient levels increases welfare. Therefore, the welfare gains of TTIP depend positively on the degree of the cross-country substitutability.

Table 4. Sensitivity Analysis: Different Cross-Country Substitutabilities

\begin{tabular}{|c|c|c|c|}
\hline & $\begin{array}{c}\rho=3 \\
\text { (benchmark) }\end{array}$ & $\rho=6$ & $\rho=8$ \\
\hline Output & $0.16 \%$ & $0.27 \%$ & $0.38 \%$ \\
\hline Trade & $17 \%$ & $33 \%$ & $42 \%$ \\
\hline Welfare & $\begin{array}{c}1.5 \% \text { of } \\
\text { consumption }\end{array}$ & $\begin{array}{c}2.7 \% \text { of } \\
\text { consumption }\end{array}$ & $\begin{array}{c}3.8 \% \text { of } \\
\text { consumption }\end{array}$ \\
\hline
\end{tabular}

In Section 4.1, we found that under the benchmark parameterization the output effect was smaller than in other TTIP studies (Berden et al. 2009, Fontagné et al. 2013 and Francois et al. 2013) in which the scenario is identical to ours. The fact that we used a lower value of the cross-country substitutability in our benchmark parameterization can explain a large part of the difference in the output results. Table 4 shows that if the cross-country substitutability is set to 6 , the output effect of TTIP increases to $0.27 \%$, which is almost as high as in the aforementioned studies, of which the average output increase is $0.32 \%$.

Our main focus is the welfare analysis of TTIP. As can be seen from Table 4, the DPV of welfare gain is as high as $3.8 \%$ of initial consumption, in the case where the cross-country substitutability is 8 . In this case, the welfare gain on a US (EU) citizen, based on the World Bank (2016) data on 2012 GDP per capita in 2014 US dollars, corresponds to a one-off 2,000 $(1,300)$ US dollars increase (approximately) in consumption. 
As discussed in Section 3, Drozd et al. (2014) emphasize that trade reacts substantially differently to persistent price changes than temporary ones that take place on business cycle frequency, and consequently estimates of the cross-country substitutability differ depending on the time horizon. In this paper, we inspect the consequences of a policy change that shift relative prices permanently. Therefore, for the question at hand, a high cross-country substitutability may be a better depiction of reality in the long term. If this is indeed the case, Table 4 shows that the welfare gains of TTIP are considerable.

An important distinction of our model relative to the TTIP studies is that we also analyze the adjustment dynamics of the economy, and trade liberalization is gradual. If trade liberalization is instant, the welfare gain of TTIP will be slightly smaller and increase from $1.5 \%$ of consumption to $1.6 \%$.

\subsection{Robustness Checks: Tariffs Only}

An important analytical issue is the quantitative relevance of the reduction in tariffs and the NTMs when implemented in isolation. Felbermayr (2015) indeed summarizes that all TTIP studies conclude that the bulk of the trade and output effects stems from cuts in NTMs. The next step is therefore to analyze the effects of a TTIP agreement that leads to the elimination of tariffs, while NTMs are kept constant. That is, the trade barrier is reduced from $20.9 \%$ to $18.1 \%$. We show results for both our benchmark value of the cross-country substitutability (3) and a higher value that is closer to one employed by the traditional trade literature (6).

Table 5 reveals that a smaller trade liberalization induces an output effect in the range of $0.06 \%$ to $0.1 \%$. These findings are in line with the other TTIP papers, excluding Felbermayr et al. 
(2015b). In a "tariffs-only" agreement, the welfare gain becomes smaller and is only $36 \%$ the baseline scenario's welfare gain. We can therefore conclude that the bulk of the welfare gain of TTIP is caused by cuts in NTMs.

Table 5. Summary of the Effects of the Tariffs-Only Agreement

\begin{tabular}{|c|c|c|c|c|c|c|}
\hline & $\begin{array}{c}\text { This study } \\
(\rho=\mathbf{3})\end{array}$ & $\begin{array}{c}\text { This study } \\
(\rho=6)\end{array}$ & $\begin{array}{c}\text { Fontagné } \\
\text { et al. } \\
(2013)\end{array}$ & $\begin{array}{c}\text { Francois } \\
\text { et al. } \\
(2013)\end{array}$ & $\begin{array}{c}\text { Felbermayr } \\
\text { et al. } \\
(2015 \mathrm{~b})\end{array}$ & $\begin{array}{c}\text { Aichele } \\
\text { et al. } \\
(2015)\end{array}$ \\
\hline $\begin{array}{c}\text { Tariff } \\
\text { reduction }\end{array}$ & $\mathbf{1 0 0 \%}$ & $\mathbf{1 0 0 \%}$ & $100 \%$ & $\begin{array}{c}98- \\
100 \%\end{array}$ & $100 \%$ & $100 \%$ \\
\hline EU GDP & $\mathbf{0 . 0 6 \%}$ & $\mathbf{0 . 1 \%}$ & $0 \%$ & $0.1 \%$ & $\begin{array}{c}0.27 \% \\
\text { (non- } \\
\text { weighted } \\
\text { EU27 } \\
\text { mean) }\end{array}$ & $0.01 \%$ \\
\hline US GDP & $\mathbf{0 . 0 6 \%}$ & $\mathbf{0 . 1 \%}$ & $0 \%$ & $0.04 \%$ & $0.75 \%$ & $0 \%$ \\
\hline Welfare & $\begin{array}{c}\mathbf{0 . 5 7 \%} \text { of } \\
\text { consumption }\end{array}$ & $\begin{array}{c}\mathbf{1 . 0 \%} \text { of } \\
\text { consumption }\end{array}$ & & & & \\
\hline
\end{tabular}

\section{Conclusions}

We contribute to the TTIP literature by employing a DSGE business cycle model that enables the welfare analysis of TTIP. We find that the discounted present value of the welfare gain of TTIP is worth $1.5 \%$ of initial consumption for a representative consumer in our baseline calibration. This is equivalent to a one-off 780 (510) US dollars increase in consumption for the US (EU) consumer.

At the same time, we need to mention the limitations of our approach because it ignores several channels through which trade liberalization in general and TTIP in particular may affect welfare. First, there are many additional gains from trade that have been elicited in the literature 
and which our model is unable to capture, including the traditional gains from specialization, the gains from access to a larger market allowing the exploitation of scale economies (Krugman, 1980), the gains from the reallocation of resources towards more productive firms resulting in higher aggregate productivity (Melitz, 2003) and the gains associated from productivity gains related to importing inputs to production (see the numerous references in the survey by Hornok and Koren (2016)). All those gains would reinforce our argument because they result in aggregate productivity increases.

Second, and against the backdrop of these gains from trade liberalization, its severe costs and the unequal distribution of those costs across affected societies also need to be considered. As Hornok and Koren (2016) report in a survey, there is ample evidence (and theory to explain it) that trade increases inequality, and that the associated costs may be larger than previously thought. However, the academic debate on the needed redistribution from the winners of liberalization towards its losers in order to achieve Pareto gains has occupied generations of trade economists. The lack of sufficient redistribution has been and continues to be a serious concern, and should be dealt with more seriously both in the public and in the academic debate. In particular, the costs of inequality and the costs of redistribution should be taken into account (Antrak et al. (2016) is a valuable start in that direction), while efforts into an analysis of labor market policies are needed to inform the public debate (Cosar (2013) and Davidson and Matusz (2006) are examples in this vein). 


\section{References}

Aichele, R., G. Felbermayr and I. Heiland, 2014. "Going Deep: The Trade and Welfare Effects of TTIP.” CESifo Working Paper No. 5150.

Anderson, J. E. and E. van Wincoop, 2004. "Trade Costs." Journal of Economic Literature 42, 691-751.

Antrak, P., A. de Gortari and O. Itskhoki, 2016. "Inequality, Costly Redistribution and Welfare in an Open Economy." Mimeo.

Basu, S. and J. G. Fernald, 1997. "Returns to Scale in U.S. Production: Estimates and Implications.” Journal of Political Economy 105, 249-283.

Bauer, M. and F. Erixon, 2015. “'Splendid Isolation’ as Trade Policy: Mercantilism and Crude Keynesianism in 'the Capaldo Study' of TTIP.” ECIPE Occasional Paper 03/2015.

Berden, K. G., J. Francois, M. Thelle, P. Wymenga and S. Tamminen, 2009. "Non-Tariff Measures in EU-US Trade and Investment-An Economic Analysis.” Report prepared for the Directorate-General for Trade, European Commission.

Bergstrand, J., P. H. Egger and M. Larch, 2013. "Gravity Redux: Estimation of GravityEquation Coefficients, Elasticities of Substitution, and General Equilibrium Comparative Statics under Asymmetric Bilateral Trade Costs." Journal of International Economics 89, 110-121.

Capaldo, J., 2014. "The Trans-Atlantic Trade and Investment Partnership: European Disintegration, Unemployment and Instability." Global Development and Environment Institute Working Paper No. 14-03.

Calvo, G. A., 1983. "Staggered Prices in a Utility Maximizing Framework." Journal of Monetary Economics 12, 383-398.

Chetty, R., A. Guren, D. Manoli and A. Weber, 2013. "Does Indivisible Labor Explain the Difference Between Micro and Macro Elasticities? A Meta-Analysis of Extensive Margin Elasticities.” NBER Macroeconomics Annual 2012 27, 1-56.

Coşar, K., 2013. "Adjusting to Trade Liberalisation: Reallocation and Labor Market Policies." Working Paper. 
Davidson, C, S. J. Matusz, 2006. "Trade Liberalisation and Compensation." International Economic Review 47, 723-747.

Dollar, D. and A. Kraay, 2004. "Trade, Growth, and Poverty.” Economic Journal 114, F22F49.

Drozd, K. A., S. Kolbin and J. B. Nosal, 2014. "Long-Run Price Elasticity of Trade and the Trade-Comovement Puzzle." Mimeo.

Felbermayr, G., 2014. "TTIP: Small Gains, High Risks?" Presentation at the 13th Munich Economic Summit May 16, 2014.

Felbermayr, G., 2015. "Understanding the Economic Models and the Projections They Produce." Accessed June 6, 2016. http://www.cato.org/publications/cato-onlineforum/understanding-economic-models-projections-they-produce.

Felbermayr, G., B. Heid and M. Larch, 2015a. “TTIP: Small Gains, High Risks?” CESifo Forum 15, 20-30.

Felbermayr, G., B. Heid, M. Larch and E. Yalcin, 2015b. "Macroeconomic Potentials of Transatlantic Free Trade: A High Resolution Perspective for Europe and the World." Economic Policy 2015, 1-42.

Feenstra, R., P. Luck, M. Obstfeld and K. Russ, 2014. "In Search of the Armington Elasticity." NBER Working Paper 20063.

Fender, J. and C. K. Yip, 2000. "Tariffs and exchange rate dynamics redux." Journal of International Money and Finance, 19, 633-655.

Fontagné, L., J. Gourdon and S. Jean, 2013. "Transatlantic Trade: Whither Partnership, Which Economic Consequences?” CEPP Policy Brief No. 01.

Francois, J., M. Manchin, H. Norberg, O. Pindyuk and P. Tomberger, 2013. "Reducing Transatlantic Barriers to Trade and Investment: An Economic Assessment." Report TRADE10/A2/A16 for the European Commission.

Ganelli, G. and J. Tervala, 2015. "Value of WTO Trade Agreements in a New Keynesian Model." Journal of Macroeconomics 45, 347-362. 
Ghironi, F., 2016. "TPP is a Structural Reform: Let's Evaluate It with Structural Models." Accessed July 7, 2016. http://voxeu.org/article/tpp-structural-reform-let-s-evaluate-itstructural-models.

Gopinath, G. and R. Rigobon, 2008. "Sticky Borders." Quarterly Journal of Economics 123, $531-575$.

Hornok, C., Koren, M., 2016. "Winners and Losers of Globalisation: Sixteen Challenges for Measurement and Theory." In Blundell, R. et al. (editors). Economics without Borders: Economic Research for European Policy Challenges. Cambridge, UK: Cambridge University Press.

Keane, M. and R. Rogersson, 2012. "Micro and Macro Labor Supply Elasticities: A Reassessment of Conventional Wisdom.” Journal of Economic Literature 50, 464-476.

Klein, P., 2000. "Using the Generalized Schur Form to Solve a Multivariate Linear Rational Expectations Model.” Journal of Economic Dynamics and Control 24, 1,405-1,223.

Krugman, P., 1980. "Scale Economies, Product Differentiation, and the Pattern of Trade." American Economic Review 70, 950-959.

Mankiw, N. G. and L. H. Summers, 1986. "Money Demand and the Effects of Fiscal Policies." Journal of Money, Credit and Banking 18, 415-429.

McCallum, B., 2001. "Software for RE Analysis." Computer Software Available at http://wpweb2.tepper.cmu.edu/faculty/mccallum/research.html.

Melitz, M. J., 2003. "The Impact of Trade on Intra-Industry Reallocations and Aggregate Industry Productivity." Econometrica 71, 1695-1725.

Petri, P. A. and M. G. Plummer, 2016. "The Economics of Analyzing the TPP.” Mimeo.

Schmitt-Grohe, S and M. Uribe, 2007. "Optimal Simple and Implementable Monetary and Fiscal Rules.” Journal of Monetary Economics 54, 1702-1725.

Raza, W., J. Grumiller, L., Taylor, T. Lance, B., Tröster and R. von Arnim, 2014. "ASSESS_TTIP: Assessing the Claimed Benefits of the Transatlantic Trade and Investment Partnership (TTIP)." Institue for International and Development Economics Discussion Papers No. 10/2014.

World Bank, 2016. Online Database. Accessed June 3, 2016. http://data.worldbank.org/. 